\title{
Precariat as a Phenomenon of The Modern Labour Market in Poland and in the European Union
}

\author{
Magdalena Knapińska \\ Associate Professor, PhD (dr hab.) \\ Poznan University of Economics and Business \\ Department of Macroeconomics and Development Research \\ Al. Niepodleglosci 10, 61-875 Poznan, Poland
}

\begin{abstract}
The aim of the article is to define precariat, a new notion, which describes the status of some social groups on the labour market. An attempt has been made to identify determinants of this phenomenon as well as its characteristic features, which justify eliciting this group on the labour market. In the first part of the article the notion of precariat is defined according to the subject literature. In the second part its economic features and range scale in Poland have been discussed, followed by the third part focusing on the EU labour market. Finally, in the fourth part, the occurrence of the phenomenon of precariat on the modern labour market has been evaluated. Final conclusions stemming from the analysis have been enclosed in the final part of the article.
\end{abstract}

Key words: Labour market, Economics, Segmentation of labour market, Dual labour market

\section{INTRODUCTION}

Labor market as one of production factors' market is the subject of analysis and studies made by economists, sociologists and also political scientists. This market is difficult to present, because the human capital, knowledge, formal qualifications and work time are transferred, and only the quantitative analysis is not enough. We should also remember that behaviors of individuals, union, employer's associations and government come into play. This specific of labor market leads into the emergence of phenomena peculiar to it.

An important reason to take the prevalence of precarity in Poland and the European Union is increasing the extent of this phenomenon in the EU countries. Transformations that accompany the economy, involving, for example, the development of modern technology, forms of communication, the transmission of the effects of work, undoubtedly lead to changes in labor relations. We can observe still changing the competencies sought after and desired by employers, which causes that the traditional model of education no longer meets the needs of the modern labor market. Perhaps the effect of this is the creation of a new social group, which is job security.

The research conducted so far on the scale of the phenomenon of unemployment, its structure often led to the conclusion that one of the major and growing problems of the modern unemployment is unemployment among young people. A negative trend is also slightly increasing unemployment of university graduates, though here it must be remembered that most of the unemployed are still, however, a person without higher education, and even secondary education.

The study of unemployment in Poland and the European Union lead to the need to explain the causes of high unemployment among young people, although sometimes it is associated with 
high, with the people in a particular age group, which is associated with the baby boom. However, the need to explain youth unemployment, is all the greater because of its devastating impact on the young generation. Therefore, an important and notable problem is the identification of phenomena occurring in today's labor market, and one of them is education on the labor market group called job security (precariat).

\section{THE CONCEPT OF PRECARIAT}

"In recent years, as in Europe, and also in Polish public discourse on flexible employment contracts to a notion junk or junk jobs. Guy Standing used to describe this phenomenon the term job security [Standing 2011], pointing to such aspects as poor in content, insecure and low- paid work, linking this with the concept of a new class of dual labor market, that is, precarity, deprived of the rights they have working on standard contracts" [Kozek, 2013, s. 145].

The concept of precarity is associated with poverty work, so this is a group of workers who, due to the increasing numbers, it becomes increasingly dangerous class. In the words of G. Standing - millions of people who live in uncertainty, are uncertain labor market, uncertain as to the apartment, and most of them are uncertain of their identity [Standing 2012]. The very term was created from the combination of two English words: precarious (insecure) and proletariat (working class poor) [Szaban 2013, p . 23] and have already entered into the dictionary of the Polish language, but in its foreign form.

In particular, to analyze the group referred to as precarity flows from the modern concept of the division of contemporary society groups, in which the classification of job security found his rear. In the literature cited G. Standing is notable contemporary existing social classes, which correspond to the Weberian concept of ideal types. These are namely the global elite consisting of major shareholders and managers of corporations, wage-earners - the category of stable employment, good working conditions and relatively high salaries, public administration employees and corporate officers, proficians - independent experts and folks professionals, consultants hired on contracts; the working class - qualified workers and service workers , with reasonable wages and unionization covered by the system of social benefits; job security dealing with low- paid, unstable and not covered by the system of social benefits segment of the labor market; unemployed - people out of work and at least part of the rootlessness of governance built around work and employment [Standing 2009, p . 102-116]. Characteristic for the system, which still has the characteristics divisions typical of Fordism, the dynamics leading to dichotomization employment to "wage-earners" and "job security ", according to the criterion of employment security and stability (and not only and not primarily height) earnings, whereby each the case is also about limited access to the benefits of the welfare state dismantled [Poławski 2012, p.129].

On the other hand, regardless of the generally impoverished precarity, in Poland, there was also a new category of "white collar" - officeariat - that is, people performing simple clerical work for low wages. The work of this kind can perform essentially any without special preparation. It is even said that usually perform it so. DUCI (the words, " do it") , people desperate to take any job and barely sustained this kind of activities. In a number of other European countries, this category is less common due to the specific situation of officials whose status is often very high in comparison with Polish (eg . in Germany, France, Portugal, Greece) [Szaban 2013, p.23]. 
In Poland it indicates that the context of precarity is that twice higher than the average unemployment rate among persons aged 18-34 years. Job security in terms of depleted content of the work is manifested by the fact that half of young workers doing a job incompatible with the direction of education, $62 \%$ of young people working on temporary contracts and more than $60 \%$ of young workers are not employed on a contract of employment, and civil law contracts [Kozek 2013, p. 145].

As noted by M. Boni temporary forms of employment, contract work and order, sometimes forcing self - offer a chance to start in the profession and can be attractive in the beginning, but at the same time do not bring satisfaction in the form of a coherent, balancing a career path in the future, do not guarantee participation training, insurance or adequate income, or - often more importantly - a long-term income security, which would be a sign of creditworthiness for banks, particularly important in the case of mortgage loans [Raport „Młodzi 2011” ( Report "Youth 2011")] .

Young people entering the labor market in Poland is diverse collectivity in terms of professional expectations - different kind of them also traveled education and level of education attained, previous contacts with the labor market, age, family situation. They include both those who are still learning or study; those who have completed their education, those who have worked and those with no work experience. Many of them are employed on temporary contracts and at the same time uncertain of their own destiny, and some, however, has a steady job and can quietly build your career. Finally there are those who already have their own families and they are single people. They differ from young workforce past decades are on average older and much better educated, have a richer social and cultural experience and a different attitude to life and work [Raport „Młodzi 2011” ( Report "Youth 2011")] .

Identification therefore a group of people belonging to the currently precarity can not be based only on age, nor solely on health. It seems, therefore, that the concept of precarity combines several features of co-occurring, and they are young age, low income, temporary employment or a temporary absence, the lack of prospects in life and financial plans for the future, lack of housing, often lack family and dislike for the establishment of due to the instability of life. Later in the development of the concept of precarity will be recognized for these qualities, but mostly the analysis will concern the economic aspects of the position and scale of precarity in Poland and the European Union.

\section{ECONOMIC ANALYSIS OF THE PHENOMENON OF PRECARITY IN POLAND}

Taking the analysis of the economic determinants of contemporary precarity should indicate the main variables describing the state of social. Well worth coming here for G. Standing as identify three groups of factors related to precarious employment. Well, first of all, job security is also a category of people who for various reasons have limited rights and possibilities of their implementation. In this sense, job security is applied to a group of people excluded from the labor market not only having access to resources, but also has limited use of social rights and civil rights. Discussion on job security repeats basically threads that come up in discussions on social exclusion and - in the economic literature - the duality of the labor market, which would consist of a segment of primary and secondary. Secondary labor market, it is the labor market of precariat, does not require special skills, unstable, lower paid, not lead to the creation of habits and norms of good work , and in fact does not require them [Poławski 2012, pp. 130-131].

Second, the job security is characterized with respect to their uncertainty and to accumulate in various dimensions security in the market. As for the following categories of factors: 
- Labor market security - defined as the ability to earn income through employment and enter the labor market (the so-called: employability)

- Employment security - adequate protection against dismissal

- Job security - protection de qualification, ability to work in their profession

- Work security - safe working conditions

- Skill reproduction security - training opportunities

- Income security - guarantees an adequate income (eg. a minimum income / minimum wages)

- Representation security - guarantees an adequate income ( eg a a minimum income / minimum wages [Standing 2011].

Thirdly, according to G. Standing on job security should be viewed in the perspective of processes. It comes with one hand, coupled with changes in the labor market and the transformation of the welfare state process of the emergence of precarity and dichotomization social structure, on the other - with characteristic path of workers "becoming more precarious", career paths analogous to the paths of promotion, but leading towards getting smaller security and greater uncertainty of income, employment, less chances to exercise their rights [Poławski 2012, p. 131].

To extract the labor resources available in the Polish economy, a group called job security should, therefore, look more closely at the chart 1 . If we assume that the current job security are young people, it can be assumed that these are people aged 15-24 years and 24-35 years. As indicated by the data Figure 1 in these groups observed the biggest difference between the coefficient of economic activity and employment rates. Their very differentiate is associated with a slightly different principle of calculating them. Now, the activity rate is the share of people employed and unemployed in the total number of people in a particular age group. In contrast, the employment rate is the percentage of people employed in the number of people in that age group. Undoubtedly, the positive aspect is that after 24 years of age significantly increases both of these measures, however, which means entering the labor market for young people. With the increase in the number of years decreases the difference between the coefficient of economic activity and employment rate which refers to the adequacy of skills, professional experience, which, however, allow people to find work and reasonably stable employment.

Figure 1. The activity rate and the employment rate by age in Poland in 2014 (\%)

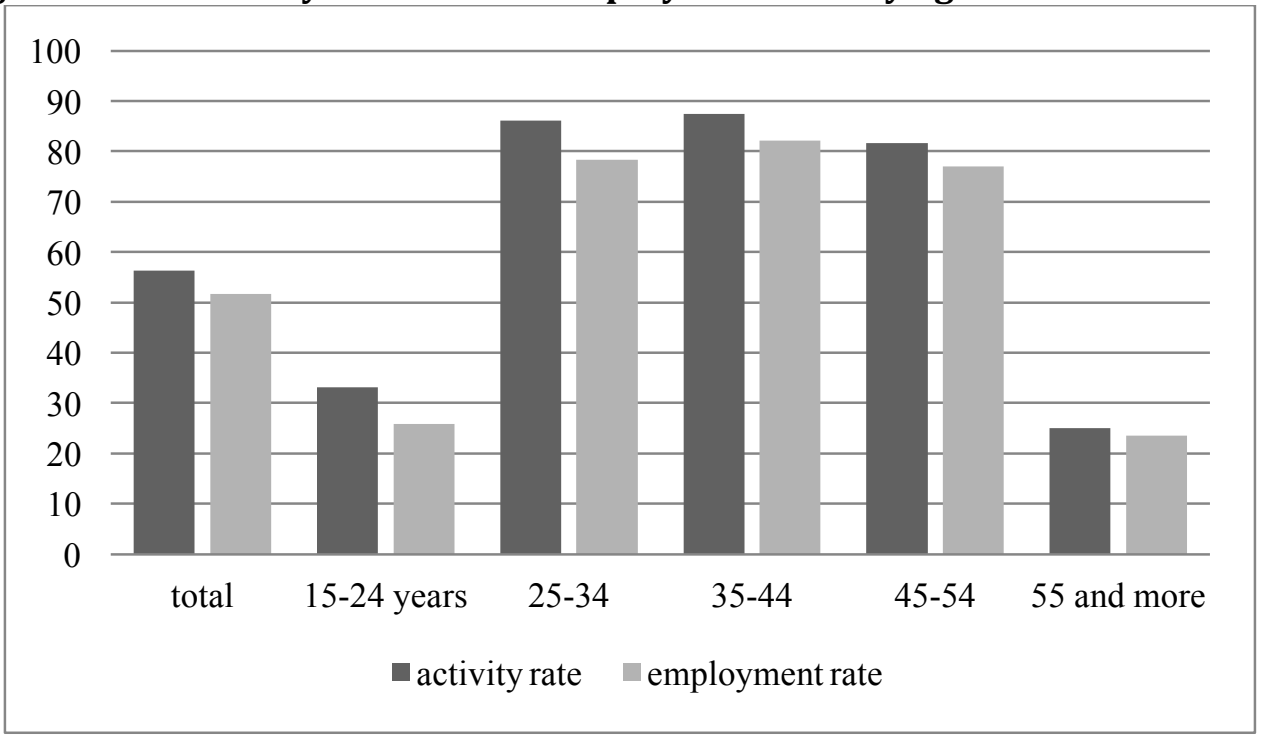

Source: [Concise Statistical Yearbook of Poland 2015, 2015, p. 119]. 
On the other hand, analyzing the working community can point to their structure because of the level of education, which is illustrated in Figure 2. As seen in 2014, the largest among the working collectivity were people with higher education, slightly lower interest represented working with post-secondary and secondary vocational and basic vocational education. These three groups having emerged in terms of education also include a total of nearly $90 \%$ of all working people, which undoubtedly shows that the economy is demand for both higher education and how and secondary education and vocational.

It is therefore concluded that intuitively understood in society, which explains such a high percentage of students in the population of twenty years. People with higher education are in fact the largest part of the working people, but should also not be forgotten that it is often the employment associated with the work on the border of their profession and does not have much connection with the skills and knowledge acquired during academic training. Very often it encountered because the situation is to work below their qualifications and professions, which several years ago was dominated by workers with secondary education.

Figure 2. The structure of employed by the level of education in 2014 (\%)

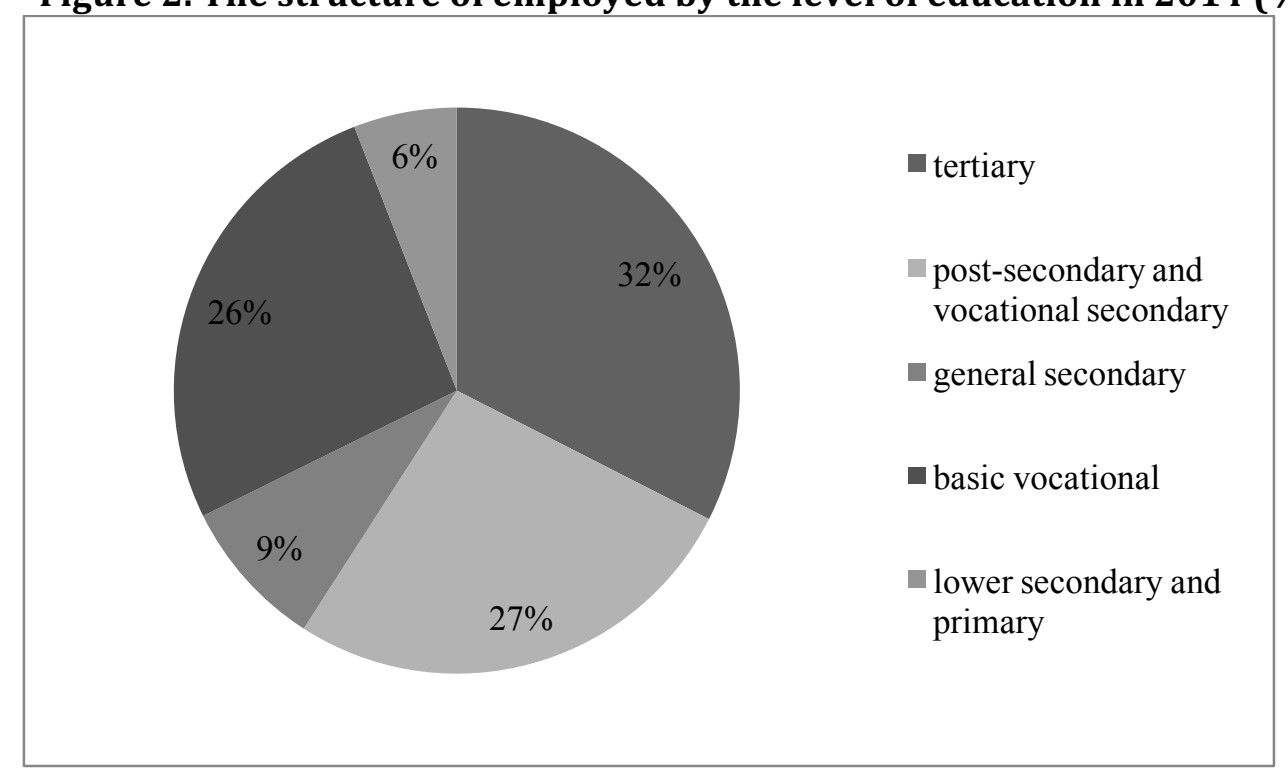

Source: [Yearbook of Labour Statistics Poland 2015, 2015, p. 136].

Moreover, it is worth to look at the data figure 3, according to which looked slightly different structure of the employed in terms of the level of education in different age groups. 
Figure 3. The structure of employed by the level of education and age in 2014 (\%)

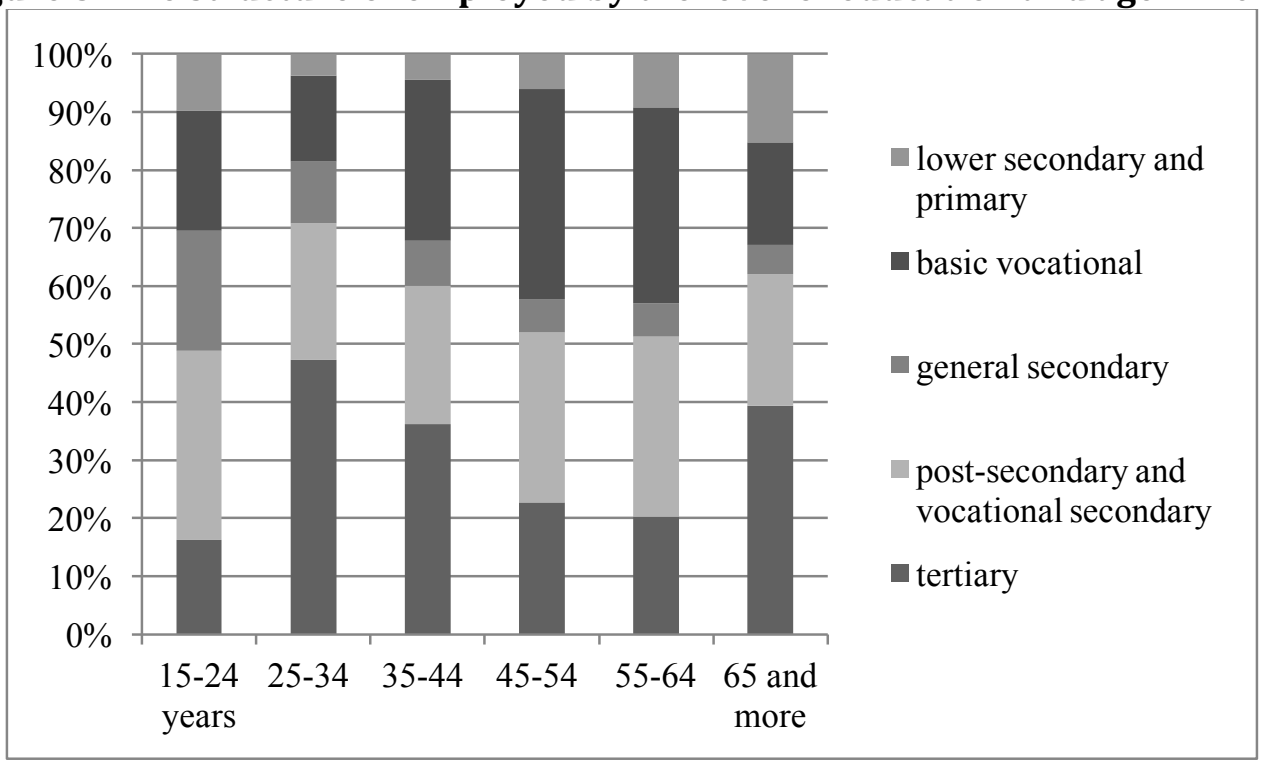

Source: [Concise Statistical Yearbook of Poland 2015, 2015, p. 123].

The data presented in Figure 3 show that in the group of people aged 25-34 had the largest number of people with higher education (almost 46\%). However, among older age were the most numerous group of employees with vocational education and their participation in the collectivities workers aged 34-45 years, 45-54 years and 55-64 years, was the order of 30$36 \%$. This indicates a significant change in the structure of education in the younger age groups, so this change lies in the fact that today the children of people with low education can almost effortlessly develop at a higher level. Generational difference occurring here is an important feature leading perhaps to the emergence of precarity Parents with low levels of education are not able to give the children skills of a career commensurate with the possessed by them education and, hence, may be young people with degrees of Master keep his job as retailers or services that do not have a lot in common with the profile of the education.

Figure 4. The structure of employed by professional groups in 2014(\%)

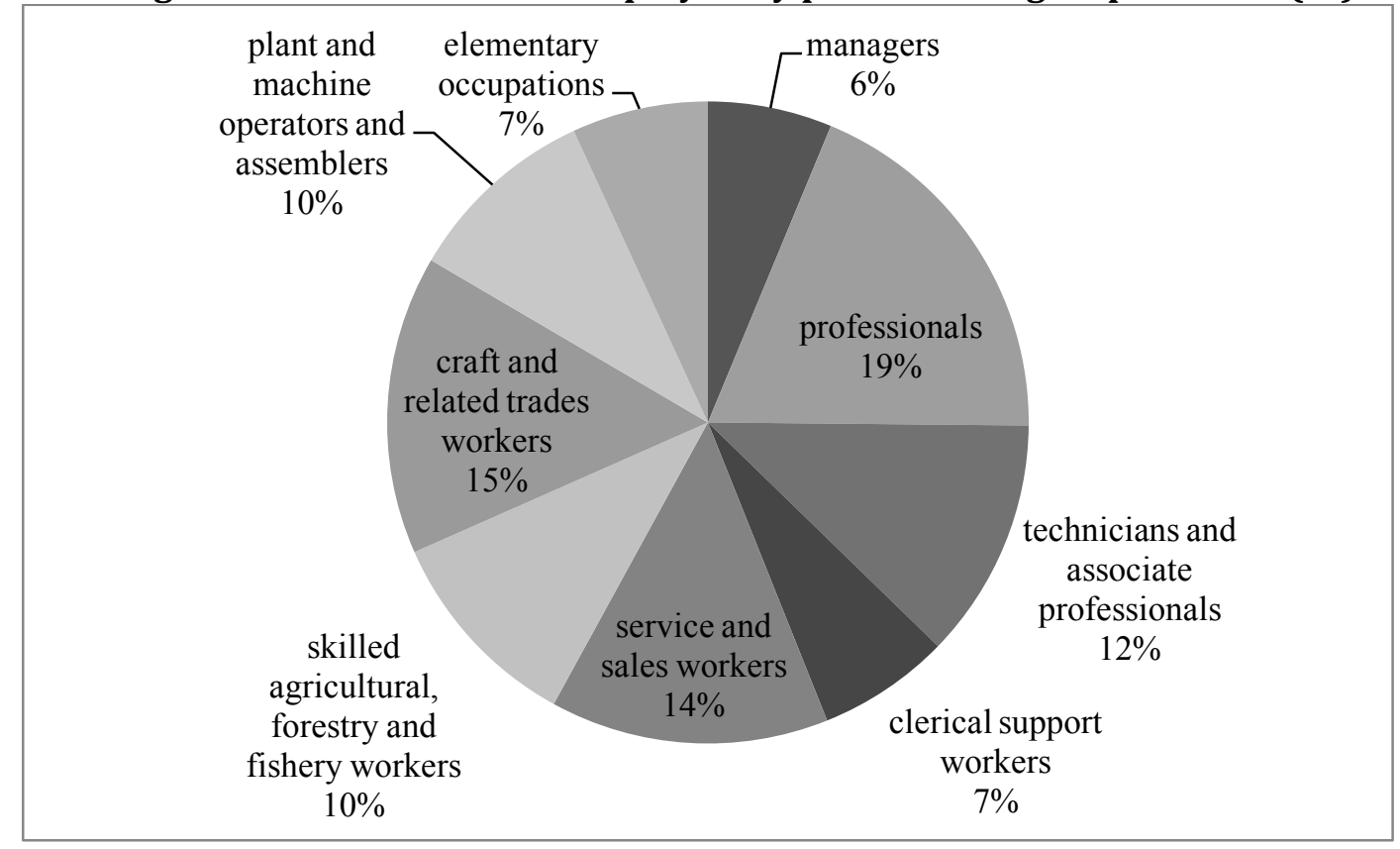

Source: [Yearbook of Labour Statistics Poland 2015, 2015, p. 137]. 
It is here, in addition, examine occupational groups represented by working in the Polish economy. And so, the relevant data refer to Figure 4. As can be seen from the data most strongly represented in the economy of a group of employees are defined as professionals, then these are industrial workers and craftsmen, and service and sales workers. Moreover, one can observe a fairly equal distribution of work among professional groups such as service and sales workers, office workers, technicians and associate professionals, occupations, whether operators and assemblers machinery and equipment. These professional groups in which they can invest up - there are people with uncertain status in the labor market. However, certainly not all employees belong to this group, because they can be characterized by certainty of employment and high wages. Specialists, however, is a group of people who use their high competence and derive benefits from the high qualifications, which won in the educational process and career path and rarely in this group may be the phenomenon of precarity.

Furthermore attention deserves analysis of the relationship of average wages in the analyzed professional groups, as illustrated in Figure 5. The best paid are representatives of public authorities, senior officials and managers. In second place were the specialists, which is a professional group can speak with rich wages and employment forms. The relatively similar level of wages was recorded in the group: technicians and other personnel average; operators and assemblers of machines and equipment as well as office workers and industrial workers and craftsmen.

Figure 5. Average gross wages in professional groups in 2014 (PLN)

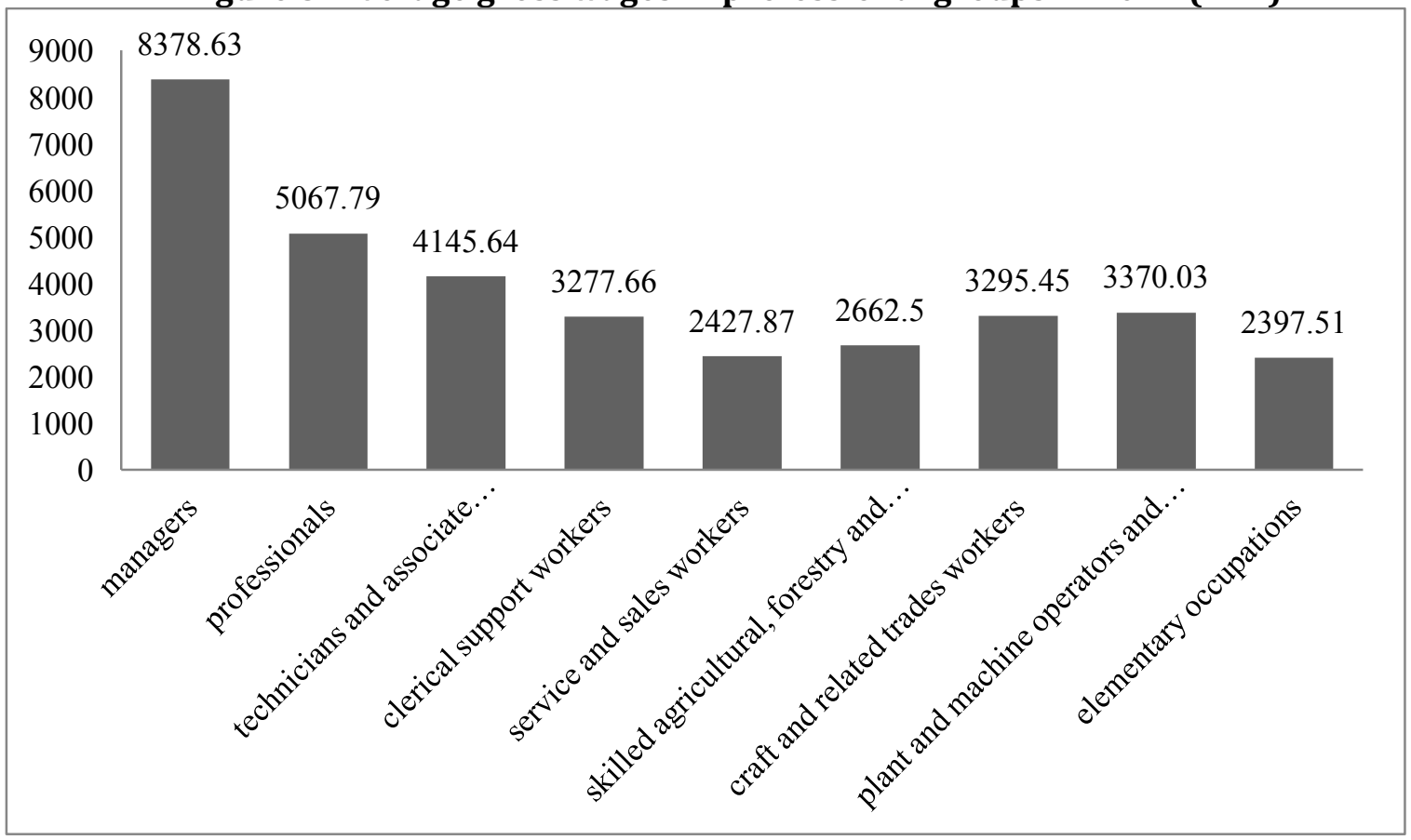

Source: [Yearbook of Labour Statistics Poland 2015, 2015, p. 303-305].

The lowest- paid workers, however, are as perform simple work, service and sales workers and farmers, gardeners, foresters and fishermen. The latter occupational group is also very large. Job security can thus be located primarily in low-paid occupational groups such as unskilled workers and service and sales workers. 


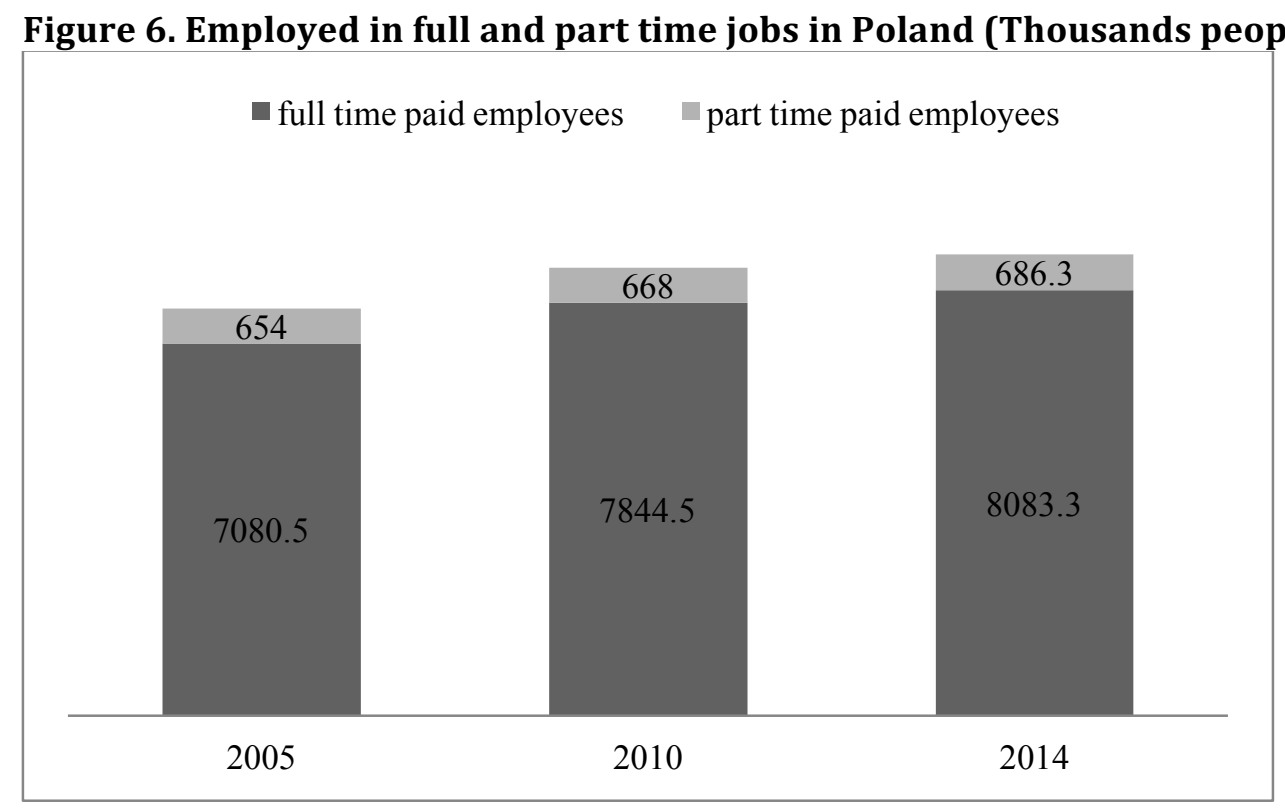

Source: [Statistical Yearbook of Republic of Poland 2015, 2015, p. 248].

It is important for the identification of precarity in Poland to identify the working structure considering working full-time and part-time work. And so, as is shown by the data of Figure 6, the number of full-time during the period increased, as did the number of part-being in 2014. This last figure fell slightly. Therefore, we can say that during the period did not make up any significant changes in the structure of the employed groups due to the full and part-time employees.

In contrast, data of Figure 7 show that the population employed in Poland was dominated by people who on average in a given year worked 40-49 hours per week and the number of these people had an increasing trend. Decreased while the number of people who have worked 50 or more hours a week. An increase in the number of characterized by a group of people, moreover, have worked an average of 30-39 hours per week and those who did not work but had a job. In the words of W. Kozek - the existing structure of the working time can be interpreted as a characteristic of society acquis who tries to achieve certain material objectives at the expense of free time and rest. But it is not clear, because the public discourse often raise the question of inability to maintain a balance of work - life because of the excessive demands of private employers in relation to employees when it comes to working time [Kozek 2013, p. 36]. 
Figure 7. Employed by hours worked in the week

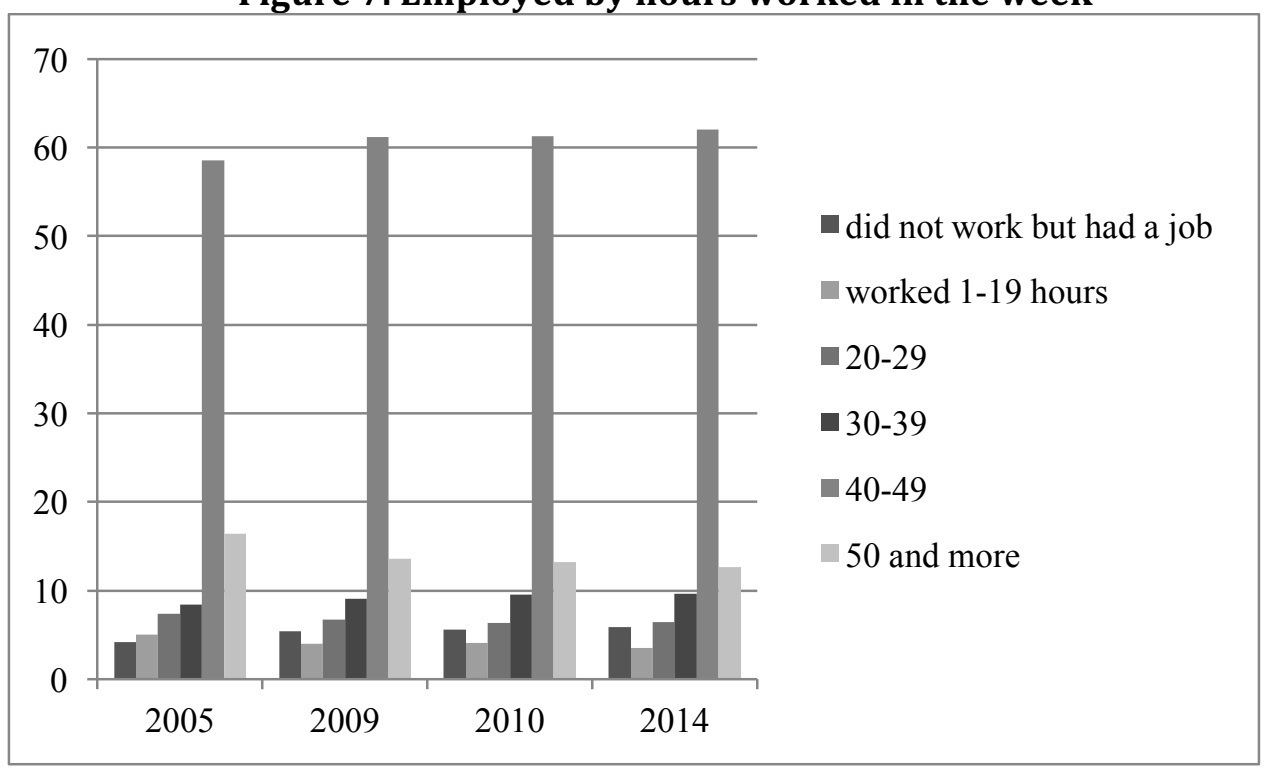

Source: [Statistical Yearbook of Republic of Poland 2015, 2015, p. 249].

\section{ECONOMIC ANALYSIS OF THE PHENOMENON OF PRECARITY IN THE EUROPEAN UNION}

In the EU - 27, the percentage of workers who have their primary work performed part-time, increased from $16.2 \%$ in 2001 to $19.5 \%$ in 2011 . The highest percentage of people employed in part-time employment were recorded in the Netherlands (49.1\% in 2011), and then subsequently in the United Kingdom, Germany, Sweden, Denmark and Austria - in each of these countries in part-time work over a quarter (from 25\% to $27 \%$ ) employed. This way of employment was, however, relatively uncommon in Bulgaria (2.4\% of employment) and Slovakia (4.1\%).

Coefficients of part- time work vary significantly depending on gender. And so, in 2011 in the EU -27 part-time employed it was almost one-third (32.1\%) of working women, much more than for men (9.0\%). In 2011 three-quarters (76.7\%) of all women employed in the Netherlands worked part-time - the highest percentage among EU Member States. In turn, in 2009 in the EU - 27, the share of employees engaged under a contract for a specified period fell to $13.6 \%$, but in 2010 . Increased to $13.9 \%$ and in 2011 . - To $14.0 \%$. While already in 2011 . More than a quarter of workers in Poland and Spain had a fixed-term contract, and in Portugal, the percentage was close to that level (22.2\%). In the other EU Member States, the share of workers on fixed-term contracts ranged from 18.2\% in the Netherlands to just $2.8 \%$ in Lithuania and $1.5 \%$ in Romania. Such significant differences between Member States in terms of propensity to employ for a specified period may, at least in part, reflect national practices, supply and demand in the labor market, expectations of employers regarding potential situations in the economic situation and the flexibility with which employers can hire or lay off workers.

[http://epp.eurostat.ec.europa.eu/statistics_explained/index.php/Employment_statistics/pl\# Umowy_o_prac.C4.99_w_niepe.C5.82nym_wymiarze_czasu_pracy_i_na_czas_okre.C5.9Blony, Access: 03.02.2016].

Interesting information provides a comparison of the precarious employment situation in European Union countries, where this phenomenon also occurs and where it has already been diagnosed. In particular, it is worth a closer look at how part- time work. This type of employment is undoubtedly the aftermath of labor market reforms that have been carried out as a result of the implementation of the concept of flexicurity in the European Union and are 
the result of increasing the flexibility of the labor market. Detailed data on part- time work concluded on the Figure 8. As a result of his data advanced countries in implementing the concept of flexicurity, they are characterized by the highest percentage of workers in part-time jobs, and they are: the Netherlands, United Kingdom, Sweden, Denmark, Germany and Austria. The smallest share of people working part-time was recorded in 2014 in: Bulgaria, Slovakia, the Czech Republic, Croatia and Hungary. This situation shows that the developed countries can "offer" to its employees part-time work and at the same time those workers may enjoy both balance in the field of work life balance, while the countries newly adopted are characterized by low wages and there part-time work is generally not a conscious choice, but a necessity related to the inability to find full-time work.

Figure 8. Part-time employed as percentage of employed, 2014 (\%)

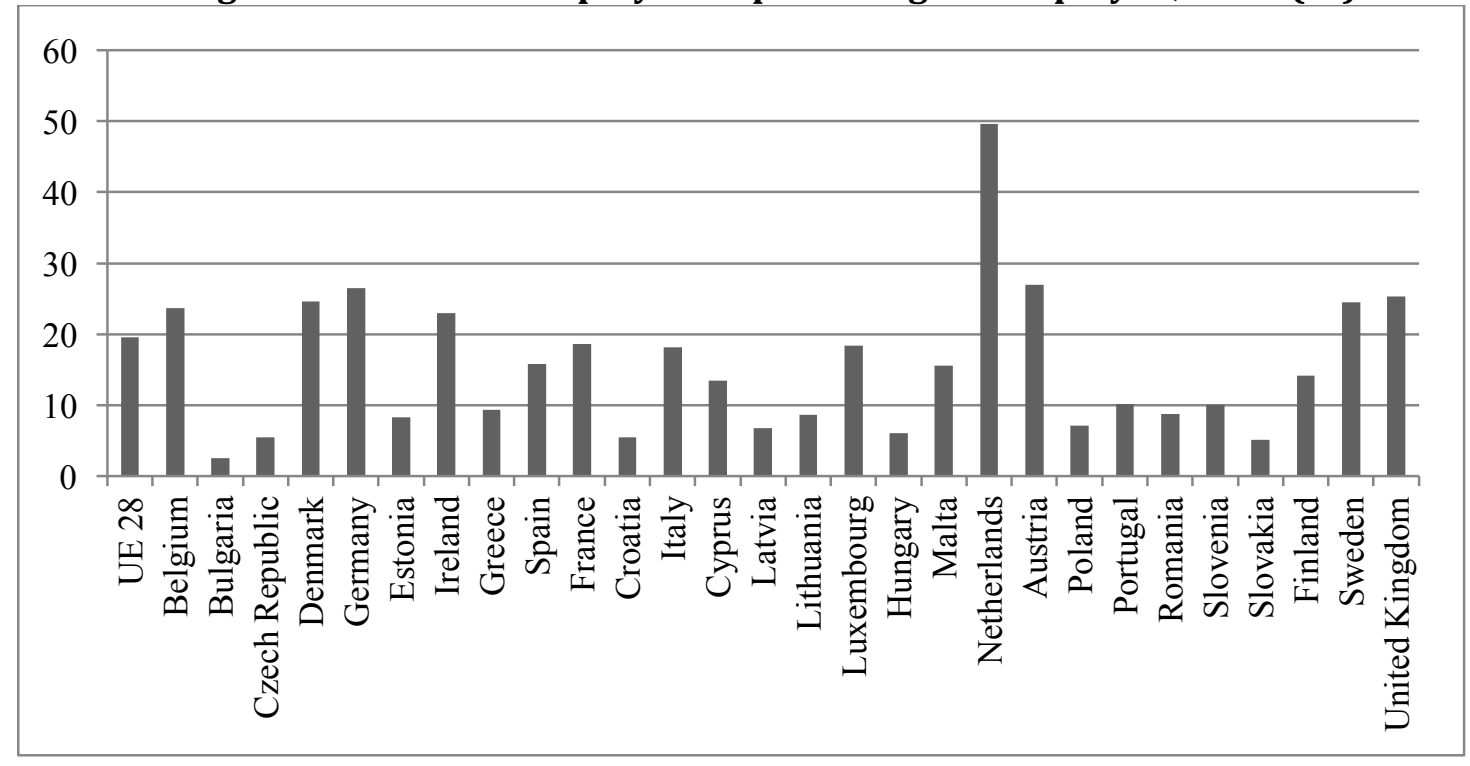

Source:

[http://epp.eurostat.ec.europa.eu/tgm/table.do?tab=table\&init=1\&language $=$ en $\&$ pcode $=$ tps 00159\&plugin=1, Access: 30.05.2016].

On the other hand, it requires examining the issue of poverty risks that may arise in connection with the performance of part-time work. The relevant data contained in the chart 9 . As one result, in all the analyzed EU countries the percentage of risk of poverty is higher in the case of underemployment than in the case of full-time. The largest, the difference in the interest exists in countries such as Bulgaria, Romania, Latvia, Lithuania, Poland, and Portugal. The smallest and the difference between the position of working full and part-time occurs in the Netherlands, Denmark, Luxembourg, and Belgium. It follows that the wages offered in the latter countries are so high that even part-time work does not cause risk of poverty. On the other hand, the reason for the lack of this threat is and also that, as stated above, those countries implementing the concept of flexicurity, which after all is associated with a more flexible labor market, but also to the development of social security and generous welfare state. So this may indicate a really high "profitability" of society to implement flexicurity, since the difference here is quite clearly visible. 
Figure 9. In-work at-risk-of-poverty rate by working time, 2014, (\%)

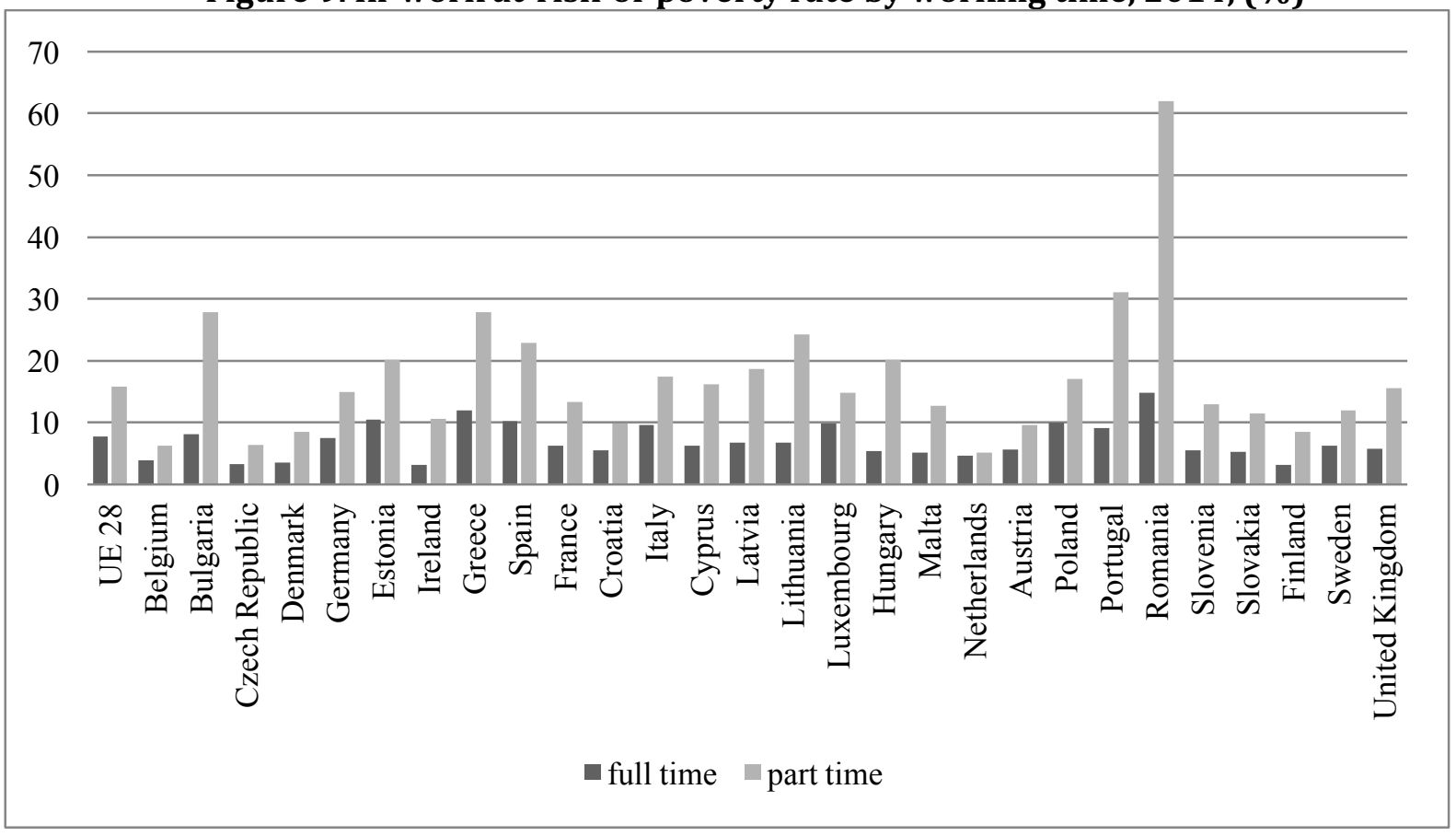

Source:

[http://epp.eurostat.ec.europa.eu/tgm/refreshTableAction.do?tab=table $\&$ plugin=1\&pcode= tessi2 50\&language=en, Access: 30.05 .2016$]$.

Additionally, one can pay attention to the scale and proportion of households which farm people belonging to precarity, which can be illustrated as households living in small extent from work ${ }^{1}$. Detailed data are included in the Figure 10. As can be seen from these data, the highest proportions living in households with low participation in the work reported in 2014. Croatia, Spain, Greece and Belgium. The lowest percentage of such households is in Luxembourg, Cyprus, Czech Republic, Poland and Slovakia. As you can see groups of separate countries are quite diverse in terms of size, GDP per capita, labor market flexibility.

In some of these countries, we can say that the work is the dominant form of revenue collection and herds such a high percentage of those households, but on the other hand, can social benefits are so low that work gives individuals much higher incomes. Finally, countries with a low percentage of living from work to countries where there may be generous system of benefits, but also the countries in which citizens live on income from capital and of assets. So it is difficult to clearly indicate which of these countries are affected by the phenomenon of precarity to a greater extent. You can only indicate that the part of people living in households with low participation in the work it can be households of precariat.

${ }^{1}$ In particular, Eurostat defines this group as those living in households with low work participation, that is, households of people aged 0 to 59 years, where the adults worked in the last year less than $20 \%$ of potential working time of full-time. 
Figure 10. People living in households with very low work intensity, 2014(\%)

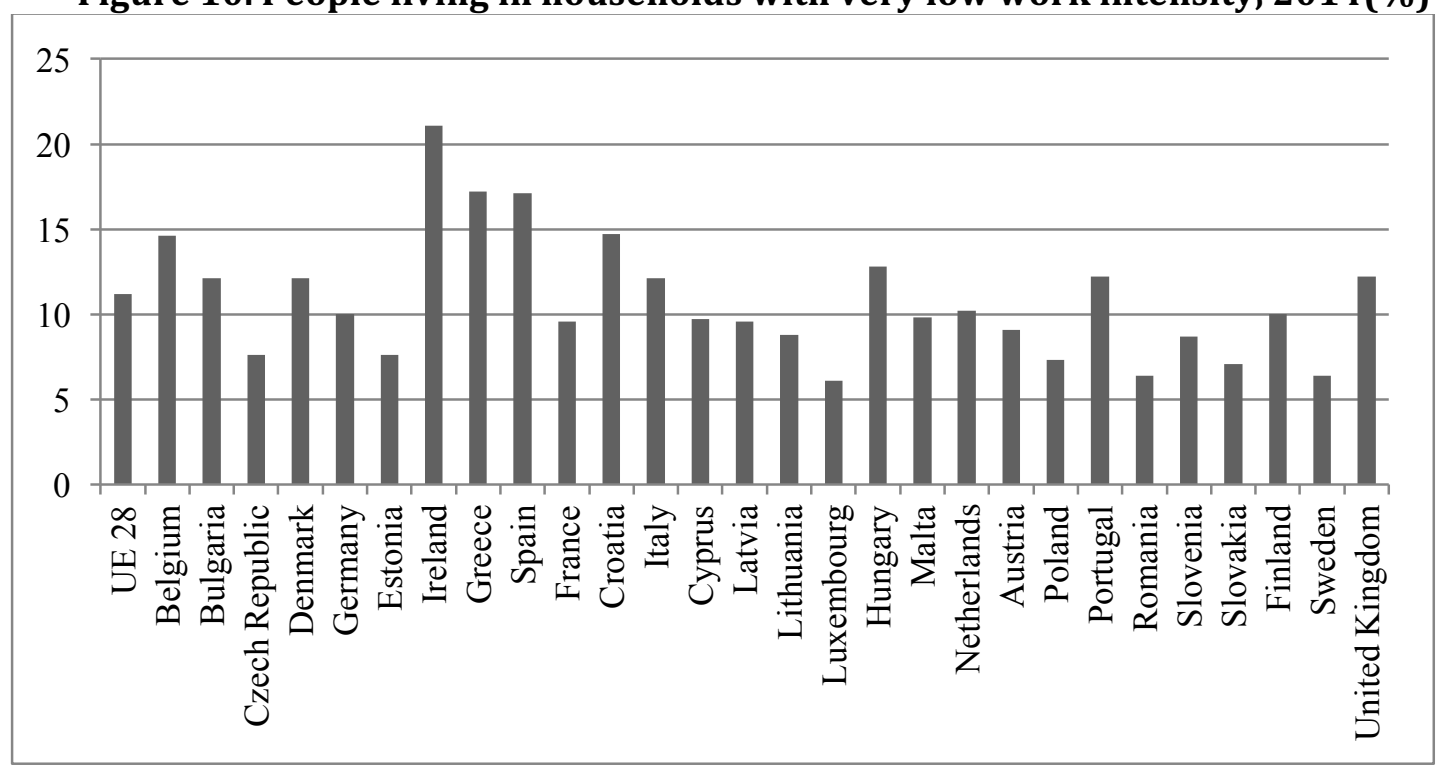

Source:

[http://ec.europa.eu/eurostat/tgm/table.do?tab=table\&init=1\&language=en\&pcode=tsdsc3 10\&plugin=1, Access: 30.05 .2016$]$

ASSESSMENT OF THE PHENOMENON OF PRECARITY IN TODAY'S JOB MARKET

The contemporary labor market creates a space strongly differentiated, where - according to M. Bednarski - next full-fledged employment opportunities exist on a significant scale of junk jobs, which create dangerous from an economic and social point of view, a group of "working poor". The whole phenomenon signaled describes the category substandard employment (undereployment) [Bednarski 2012, p. 36] . Group social precarity seems to be just part of such employment, and in the literature in this way it is portrayed.

At the same time it should be noted that the emergence of the phenomenon of precarity is somewhat the result of the implementation of the concept of flexicurity, and at least one of its pillars, which is a flexible labor market. The literature also emphasizes that the elements of a flexible labor market is the flexibility of employment, working hours, wages and labor supply. As pointed out by E. Kwiatkowski important for employment flexibility it has the degree of development of atypical forms of employment. This is about employment on a contract basis, on the implementation of specific tasks, part- time work, employment under fixed-term contracts, work on call, work part-time, work at home or permanent employment of workers with variable working time [Kwiatkowski 2002, p.286]. The use of these forms of employment called atypical allows employers to more easily hire and fire employees and the employee a better opportunity to find a new job in the event of its loss. That flexibility of the labor market therefore has the advantages of visible both from the perspective of the employer and the employee.

In addition, it must be emphasized that the component of the idea of flexicurity is also a generous welfare state in ensuring the social security of citizens in the event of job loss. This pillar of flexicurity is often unknown and underestimated by employers and trade union members. Finally, the third element discussed here is the idea of active labor market policy, which is to help the reintegration into the labor market and the departure from the status of a beneficiary of social assistance. These three pillars of the Danish flexicurity must occur at the same time and be implemented at the same time, so as to avoid the creation of cartoons focused on only one element of this interesting concept. 
The occurrence of precarity is undoubtedly a negative phenomenon in today's labor market. Its components in the form of low activity of professional young people, working below their qualifications, no job security and social protection make especially among young people on the labor market is perceived negatively.

It can also be noted that in the economy is also some other phenomenon which is called. freelancing - that also work without a contract at the time, and connecting orders for the various entities that are orders depend on the performance of services of highly specialized and often highly paid (eg. in the IT industry, with a range of programming, etc.). Summary of these two modern phenomena indicates that modern workers do not always desire the employment relationship based on a contract of employment. Moreover, there are many examples of high- valuing self-employment and running your own business, as a greater opportunity to use their full professional potential.

The above analysis however, concerned the potential issues and phenomena in which one could discern the existence of precarity, show at the same time as it is difficult to classify the phenomenon and consider them as a sign of the occurrence of precarity on the labor market in Poland, the European Union countries.

\section{CONCLUSIONS}

As for the conclusions of the study, you indicate that in Poland we have to deal with the changes in the labor market, which primarily relate to young people. Group of people aged 25 to 34 years have been characterized by a higher level of education than the other, but not always, this translates into the possibility of finding well-paid jobs in the primary labor market with a safe and secure employment. Moreover, among young people it can be seen - which results from the literature - a little bit different attitudes related to making choices in life between work and family life, or lives alone, or in the family.

As for the number of employees in different occupational groups, this one could observe a fairly uniform "distribution" of human resources between the medium and low level management, for example: occupations related services personnel and sales, technicians, machine operators. In addition, the relationship of wages indicates that in these groups salaries are lower than in the more privileged groups of specialists or senior officials and managers. This is undoubtedly the conclusion that the unfavorable situation of young workers, who are mainly low-paid employment in the secondary labor market and hard for them to "move" on the primary market.

The dominant form of employment in Poland is still work full-time jobs, and the average hours worked per year is close to 40 hours per week, which puts our country among the countries "on output" and determines the relatively low labor productivity.

In turn, the European Union can be seen that there is quite a clear dichotomy between the rich countries and new member states in a range of variables. And you could point out that, paradoxically, countries with greater flexibility in the labor market that have implemented the concept of flexicurity, characterized by both a higher percentage of people employed part-time jobs, while a lower percentage of measuring the risk of poverty.

The above features of the contemporary labor market clearly indicate that this market there are changes associated with changes in economic structures, technological changes and technical. Another group of factors determining the situation on the labor market is undoubtedly the situation in the economic situation, which has an impact on the extent and 
nature of labor demand reported by employers. Finally, an important determinant of the situation on the labor market are also social and cultural changes that manifest themselves in the perception of the role of work in people's lives. The search for a balance between professional life and private and family life is becoming more and more common condition that affects the choice between work time and free time. Therefore, the phenomenon of precarity is one of those phenomena in the labor market, which affect a wide variety of factors and it is both an economic and a social and sociological.

\section{References}

Bednarski, M. (2012), Zatrudnienie na czas określony. Perspektywa pracodawców, in: Bednarski, M., Frieske, K.W. (ed.), Zatrudnienie na czas określony w polskiej gospodarce. Społeczne i ekonomiczne konsekwencji zjawiska,

Warsaw: Instytut Pracy i Spraw Socjalnych, p. 36-66.

Concise Statistical Yearbook of Poland 2015, (2015), Warsaw: Central Statistical Office.

Kozek, W. (2013), Rynek pracy. Perspektywa instytucjonalna, Warsaw: Wydawnictwa Uniwersytetu Warszawskiego.

Kwiatkowski, E. (2002), Bezrobocie. Podstawy teoretyczne, Warsaw: Wydawnictwo Naukowe PWN.

Poławski, P. (2012), Prekariat: stabilizacja w gorszym segmencie rynku pracy, in: Bednarski, M., Frieske, K.W. (ed.), Zatrudnienie na czas określony w polskiej gospodarce. Społeczne i ekonomiczne konsekwencji zjawiska, Warsaw: Instytut Pracy i Spraw Socjalnych, p. 122-147.

Raport „Młodzi 2011”, (2011), Warsaw: Kancelaria Prezesa Rady Ministrów.

Standing, G. (2009), Work after Globalization: Building Occupational Citizenship, Northampton: Edward Elgar, MA. Standing, G. (2011), The Prekariat: the New Dangerous Class, “Policy Network”, 24 may 2011.

Standing, G. (2012), The Precariat is growing angry. Interview: http://boilingfrogs.info/2012/11/08/guystanding-precariat-angry, access 3th February.2016

Statistical Yearbook of The Republic of Poland 2015 (2015), Warsaw: Central Statistical Office.

Szaban, J. (2013), Rynek pracy w Polsce i Unii Europejskiej, Warsaw: Wydawnictwo Difin.

Yearbook of Labour Statistics Poland 2015 (2015), Warsaw: Central Statistical Office.

\section{Web Sites:}

http://epp.eurostat.ec.europa.eu 